\title{
Twitch potentiating effects of theophylline on rat diaphragm are enhanced by foreshortening
}

\author{
G. Gayan-Ramirez, N. Buts, M. Decramer
}

Twitch potentiating effects of theophylline on rat diaphragm are enhanced by foreshortening. G. Gayan-Ramirez, N. Buts, M. Decramer. CERS Journals Ltd 1994

ABSTRACT: In patients with chronic obstructive pulmonary disease (COPD) and acute respiratory failure, acute hyperinflation is likely to induce foreshortening of inspiratory muscles. Since no data are available on the effects of inotropic agents at lengths below the optimal length $\left(L_{0}\right)$, we compared the effects of theophylline on forty rat diaphragm bundles placed at $\mathrm{L}_{0}$ and at $70 \% \mathrm{~L}_{0}$.

Twitches and tetanic stimulations were recorded before and after addition of theophylline, in concentrations of $20,100,200$ or $400 \mathrm{mg} \cdot l^{-1}$.

Compared with values obtained before theophylline, twitch tension $\left(P_{t}\right)$ and maximal tetanic tension $\left(P_{0}\right)$ of the bundles placed at $L_{0}$ slightly decreased at 20 and $100 \mathrm{mg} \cdot l^{-1}$ whereas a clear increase in $P_{t}$ was obtained at $400 \mathrm{mg} \cdot l^{-1}(15 \pm 21 \%$ $($ mean \pm SD $))$. In contrast, $P_{t}$ of the bundles placed at $70 \% L_{0}$ increased with all theophylline concentrations, and vastly more than at $\mathrm{L}_{0}\left(e . g\right.$. at $400 \mathrm{mg} \cdot l^{-1}: 74 \pm 34 \%$, $p<0.05$ ); whereas $P_{0}$ slightly decreased, except at $400 \mathrm{mg} \cdot l^{-1}$. Moreover, the difference between the effects at $L_{0}$ and at $70 \% L_{0}$ increased with increasing theophylline concentrations.

We conclude that even at low, in vivo attainable serum levels, theophylline exerted greater positive inotropic effects on twitch tension $\left(P_{t}\right)$ of rat diaphragm when foreshortened than when at optimal length.

Eur Respir J., 1994, 2, 292-297.
Respiratory Muscle Research Unit, Laboratory for Pneumology and Respiratory Division, University Hospital, Katholieke Universiteit Leuven, Leuven, Belgium.

\section{Respiratory Division \\ University Hospital \\ Weligerveld 1 \\ B-3212 Pellenberg \\ Belgium}

Correspondence: M. Decramer

Keywords: Contractile properties inotropic agents

respiratory mechanics

respiratory muscles

Received: February 171993

Accepted after revision August 81993

Supported by a grant from the "Fonds voor Geneeskundig Wetenschappelijk Onderzoek".
Since they may improve the function of respiratory muscles, methylxanthines, such as theophylline, have received considerable attention in recent years. It has been suggested that they increase the force developed by respiratory muscles in animals [1-10], and in normal subjects [11, 12], as well as in patients with chronic obstructive pulmonary disease (COPD) [13]. In these patients, hyperinflation may be extremely severe [14]. It presumably shortens inspiratory muscles, and thereby displaces them to a less advantageous position of their length-tension curve. Although adaptive changes are likely to occur in chronic hyperinflation [15], the diaphragm is still expected to be foreshortened in acute hyperinflation $[14,16]$.

The effects of theophylline on contractile properties of the foreshortened diaphragm have, to the best of our knowledge, never been studied. The results of such a study would be of potential conceptual interest to respiratory muscle pharmacotherapy in COPD patients, who often present with acute hyperinflation. The present study was, thus, designed to examine the effects of theophylline on contractile properties of rat diaphragm placed at optimal length $\left(\mathrm{L}_{\mathrm{o}}\right)$, and to compare them with those obtained at $70 \% \mathrm{~L}_{\mathrm{o}}$ which is a considerably shorter length, reached at total lung capacity [14].

\section{Materials and methods}

Forty male Wistar rats weighing $350-400 \mathrm{~g}$ were anaesthetized with sodium pentobarbital (Nembutal, 60 $\mathrm{mg} \cdot \mathrm{kg}^{-1}$ i.p.). Each animal was tracheostomized and mechanically ventilated with an $\mathrm{O}_{2}$ enriched gas mixture. The diaphragm was quickly removed through a laparotomy, and immediately immersed in a cooled, oxygenated Krebs solution, containing (in $\mathrm{mM}$ ): $\mathrm{NaCl}$ 137, $\mathrm{KCl} 4, \mathrm{CaCl}_{2} 2, \mathrm{MgCl}_{2} 1, \mathrm{KH}_{2} \mathrm{PO}_{4} 1, \mathrm{NaHCO}_{3} 12$, glucose 6.5. Two small bundles were obtained by careful dissection parallel to the long axis of the fibres. Silk sutures were firmly tied to both ends of the bundle to serve as anchoring points.

Each bundle was then placed within the external chamber of a jacketed tissue bath, containing Krebs solution, maintained at $37^{\circ} \mathrm{C}$ and perfused with a $95 \% \mathrm{O}_{2}$ and $5 \%$ $\mathrm{CO}_{2}$ mixture. The $\mathrm{pH}$ varied between 7.4-7.5. One end of the bundle was tied to a rigid support, while the other was fastened to an isometric force transducer, mounted on a micrometer. The muscle was placed between two large platinum stimulating electrodes.

After a $15 \mathrm{~min}$ thermoequilibration period, the bundles were placed at $\mathrm{L}_{\mathrm{o}}$, defined as the length at which peak twitch force was obtained. Maximal response was 
estimated by twitch amplitude. Stimulation was delivered through a Harvard 50-5016 stimulator (Edenbridge, Kent, UK) connected in series to a power amplifier made from power one model HS24-4.8 developed by the computer technology resources center, University of Virginia (R.J. Evans, 1983). Maximal stimulation was achieved at approximately $34 \mathrm{~V}$. The voltage was then increased by $20 \%$ to ensure supramaximal stimulation. Isometric force was measured with a Maywood force transducer (Maywood Ltd, Hampshire, UK). The signal was amplified and recorded on a hot pen recorder (W \& W Electronics, Basel, Switzerland). Measurements were made directly from the recorder tracings.

The following measurements were then performed: 1) Twitch characteristics - two twitches were recorded at $\mathrm{L}_{\mathrm{o}}$ to determine maximal twitch tension $\left(\mathrm{P}_{\mathrm{t}}\right)$. The average value was used as $\mathrm{P}_{t}$. Time to peak tension (TPT) and half relaxation time (1/2RT) were also measured; 2$)$ Maximal tetanic force - the bundles at $\mathrm{L}_{\mathrm{o}}$ were then stimulated tetanically at $160 \mathrm{~Hz}$, during $350 \mathrm{~ms}$, with supramaximal $0.2 \mathrm{~ms}$ voltage pulses, to obtain a clear plateau in force generation. Tetanic tension $\left(\mathrm{P}_{\mathrm{o}}\right)$ was recorded as the maximal tension at $160 \mathrm{~Hz}$.

Subsequently, one bundle was placed at $70 \% \mathrm{~L}_{\mathrm{o}}$, and was stimulated as described above.

Theophylline was added to each muscle bath to obtain a concentration of $20,100,200$ or $400 \mathrm{mg} \cdot \mathrm{l}^{-1}$. After 30 min equilibration time, the same measurements (two twitches and one tetanic stimulation) were repeated for each bundle. Each pair of bundles was studied simultaneously, and 10 pairs were obtained at each concentration.

Finally, each muscle bundle was removed from the bath and its length, thickness and width were measured at $\mathrm{L}_{\mathrm{o}}$ using a micrometer. The bundle was blotted dry and weighed. Cross-sectional area (CSA) was calculated by dividing weight by specific density (1.056) and muscle length. Twitch forces and tetanic forces were expressed per unit cross-sectional area. The twitchtetanus ratio $\left(\mathrm{P}_{\mathrm{t}} / \mathrm{P}_{\mathrm{o}}\right)$ was calculated for each muscle bundle. The total duration of an experiment was about one hour.

Data were collected from a total of 40 pairs of bundles with a tetanic force of at least $2 \mathrm{~kg} \cdot \mathrm{cm}^{-2}$. Means \pm SD were calculated and are represented in the text and the figures. Data obtained before theophylline were compared to those obtained after, using two-way analysis of variance. Differences between means were assessed by a subsequent Duncan test.

\section{Results}

\section{Comparison of bundle properties at $L_{o}$}

Geometric properties of the bundles. No significant differences in weight $(0.024 \pm 0.01$ versus $0.025 \pm 0.01 \mathrm{~g})$ were present at $\mathrm{L}_{\mathrm{o}}$ between the bundles further studied at $\mathrm{L}_{\mathrm{o}}$ and those further studied at $70 \% \mathrm{~L}_{\mathrm{o}}$. There were also no differences in thickness $(0.59 \pm 0.16$ versus $0.59 \pm 0.15$ $\mathrm{mm})$, or CSA $\left(0.011 \pm 0.003\right.$ versus $\left.0.011 \pm 0.003 \mathrm{~cm}^{2}\right)$. Only a small difference in $\mathrm{L}_{\mathrm{o}}(2.01 \pm 0.25$ versus $2.19 \pm 0.25$ $\mathrm{cm})$ was observed, reaching statistical significance $(\mathrm{p}<0.05)$.

Contractile properties of the bundles. No significant differences in $\mathrm{P}_{t}, \mathrm{P}_{\mathrm{o}}$, TPT and $1 / 2 \mathrm{RT}$ were observed at $\mathrm{L}_{\mathrm{o}}$ between the bundles studied at $\mathrm{L}_{\mathrm{o}}$ and those further studied at $70 \% \mathrm{~L}_{\mathrm{o}}$, for each theophylline concentration except $200 \mathrm{mg} \cdot \mathrm{l}^{-1}$ (table 1). At this concentration, $\mathrm{P}_{\mathrm{t}}$ of the bundles which were later shortened, was greater than that of bundles subsequently studied at $\mathrm{L}_{\mathrm{o}}$. Consequently, $\mathrm{P}_{\mathrm{t}} / \mathrm{P}_{\mathrm{o}}$ was also significantly greater (table 1 ).

\section{Effects of theophylline on contractile properties at $L_{o}$}

Twitch characteristics. With the exception of the 200 $\mathrm{mg} \cdot l^{-1}$ theophylline concentration, statistically significant differences in $\mathrm{P}_{\mathrm{t}}$ were observed after theophylline, compared to values obtained before (fig. 1a). $P_{t}$ slightly decreased after 20 or $100 \mathrm{mg} \cdot l^{-1}$ theophylline $(-22 \pm 12 \%$ and $-13 \pm 11 \%$, respectively, $\mathrm{p}<0.05)$ but increased with $400 \mathrm{mg} \cdot l^{-1}(15 \pm 22 \%, \mathrm{p}<0.05)$. TPT increased significantly with $400 \mathrm{mg} \cdot l^{-1}$ and $1 / 2 \mathrm{RT}$ with $200 \mathrm{mg} \cdot l^{-1}$ (table 2).

Table 1. - Contractile properties of bundles at $\mathrm{L}_{\mathrm{o}}$ before theophylline

\begin{tabular}{lcccccccc}
\hline & \multicolumn{2}{c}{ Before $20 \mathrm{mg} \cdot l^{-1}$} & \multicolumn{2}{c}{ Before $100 \mathrm{mg} \cdot l^{-1}$} & \multicolumn{2}{c}{ Before $200 \mathrm{mg} \cdot l^{-1}$} & \multicolumn{2}{c}{ Before $400 \mathrm{mg} \cdot l^{-1}$} \\
& $\mathrm{~L}_{\mathrm{o}}$ & $\mathrm{L}_{\mathrm{o}}\left(70 \% \mathrm{~L}_{\mathrm{o}}\right)$ & $\mathrm{L}_{\mathrm{o}}$ & $\mathrm{L}_{\mathrm{o}}\left(70 \% \mathrm{~L}_{\mathrm{o}}\right)$ & $\mathrm{L}_{\mathrm{o}}$ & $\mathrm{L}_{\mathrm{o}}\left(70 \% \mathrm{~L}_{\mathrm{o}}\right)$ & $\mathrm{L}_{\mathrm{o}}$ & $\mathrm{L}_{\mathrm{o}}\left(70 \% \mathrm{~L}_{\mathrm{o}}\right)$ \\
\hline $\mathrm{P}_{\mathrm{t}} \mathrm{g} \cdot \mathrm{cm}^{-2}$ & $766 \pm 161$ & $784 \pm 216$ & $684 \pm 139$ & $706 \pm 116$ & $697 \pm 111$ & $924 \pm 130 *$ & $660 \pm 123$ & $665 \pm 197$ \\
$\mathrm{TPT} \mathrm{ms}$ & $22.9 \pm 5.4$ & $20.2 \pm 4.1$ & $23.2 \pm 5.2$ & $20.6 \pm 2.7$ & $23.6 \pm 4.1$ & $20.0 \pm 0.9$ & $17.8 \pm 3.9$ & $19.6 \pm 1.0$ \\
$1 / 2 \mathrm{RT} \mathrm{ms}$ & $41.7 \pm 6.8$ & $38.1 \pm 8.8$ & $43.8 \pm 6.6$ & $42.6 \pm 3.8$ & $40.4 \pm 8.0$ & $38.5 \pm 6.7$ & $41.3 \pm 11.3$ & $38.8 \pm 7.0$ \\
$\mathrm{P}_{\mathrm{o}} \mathrm{kg} \cdot \mathrm{cm}^{-2}$ & $2.96 \pm 0.45$ & $2.96 \pm 0.76$ & $2.69 \pm 0.46$ & $2.71 \pm 0.38$ & $2.76 \pm 0.47$ & $3.03 \pm 0.34$ & $2.51 \pm 0.34$ & $2.51 \pm 0.49$ \\
$\mathrm{P}_{\mathrm{t}} / \mathrm{P}_{\mathrm{o}}$ & $0.26 \pm 0.03$ & $0.27 \pm 0.03$ & $0.26 \pm 0.05$ & $0.26 \pm 0.03$ & $0.25 \pm 0.02$ & $0.31 \pm 0.03 *$ & $0.26 \pm 0.03$ & $0.28 \pm 0.04$
\end{tabular}

Note that " $\mathrm{L}_{\mathrm{o}}$ " denotes bundles that were subsequently studied at optimal length $\left(\mathrm{L}_{\mathrm{o}}\right)$; while $" \mathrm{~L}_{\mathrm{o}}\left(70 \% \mathrm{~L}_{\mathrm{o}}\right)$ " denotes bundles further studied at $70 \% \mathrm{~L}_{\mathrm{o}}$. All contractile properties shown in this table are obtained at $\mathrm{L}_{\mathrm{o}}$ in both groups. Data are presented as mean \pm SD. $P_{t}$ : twitch tension; $P_{0}$ : tetanic tension; $P_{t} / P_{0}$ : twitch to tetanus ratio; TPT: time to peak tension; $1 / 2 R T$ : half relaxation time. $*$ : $\mathrm{p}<0.05$ comparison at $\mathrm{L}_{\mathrm{o}}$ between the two groups. 

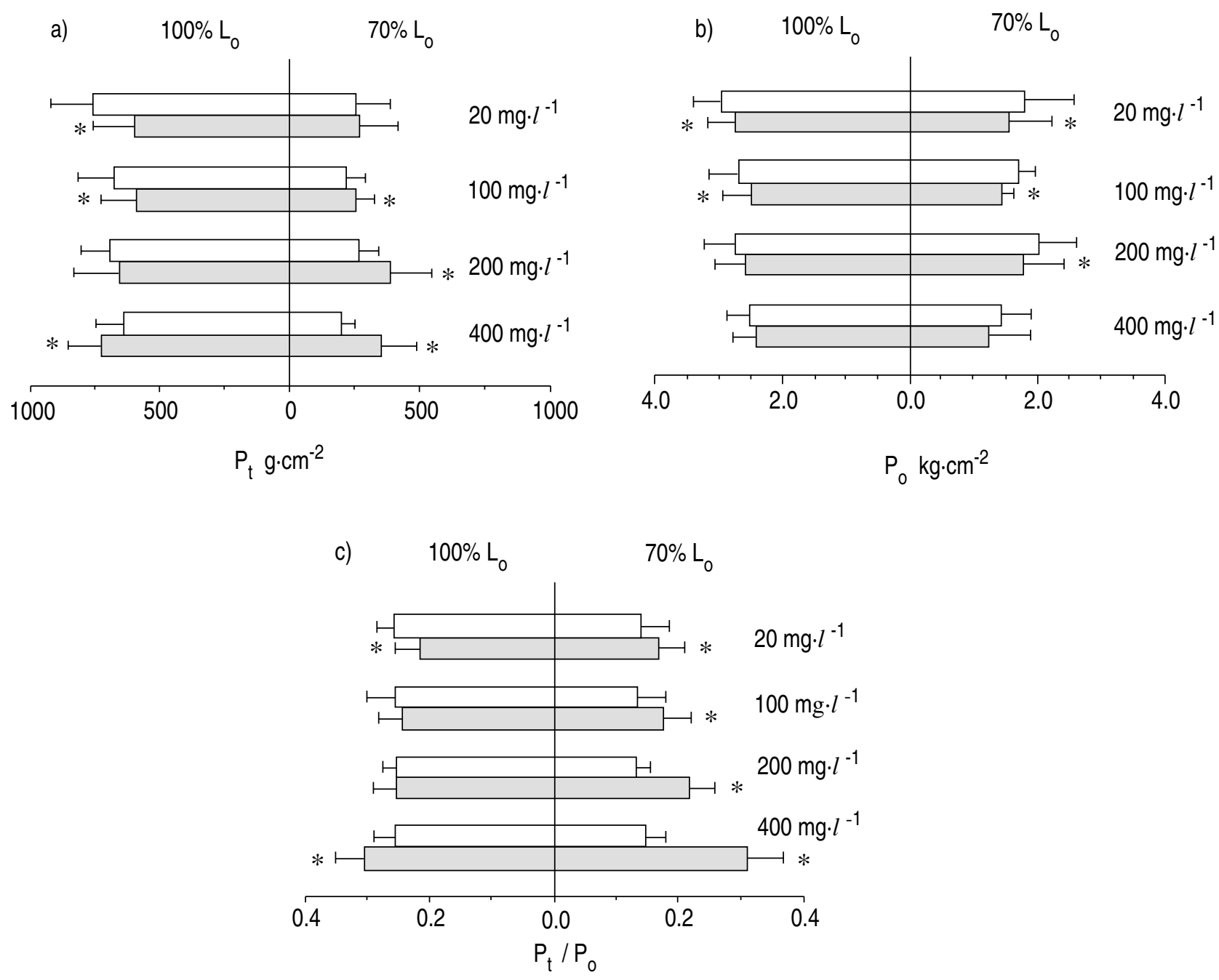

Fig. 1. - Absolute values (mean \pm SD) of: a) $\mathrm{P}_{\mathrm{t}}$; b): $\mathrm{P}_{\mathrm{o}}$; and c) $\mathrm{P}_{\mathrm{t}} / \mathrm{P}_{\mathrm{o}}$ obtained at $100 \% \mathrm{~L}_{\mathrm{o}}$ and $70 \% \mathrm{~L}_{\mathrm{o}}$ before theophylline (open bars), at different concentrations 30 min later (hatched bars). ${ }^{*}: \mathrm{p}<0.05$. $\mathrm{L}_{\mathrm{o}}$ : optimal length; $\mathrm{P}_{\mathrm{t}}$ : twitch tension; $\mathrm{P}_{\mathrm{o}}$ : tetanic tension; $\mathrm{P}_{\mathrm{t}} / \mathrm{P}_{\mathrm{o}}$ : twitch to tetanus ratio.

Table 2. - Time to peak tension (TPT) and half relaxation time (1/2RT) obtained at $\mathrm{L}_{0}$ and $70 \% \mathrm{~L}_{0}$ before and after each theophylline concentration

\begin{tabular}{|c|c|c|c|c|}
\hline & \multicolumn{2}{|c|}{$\mathrm{L}_{\mathrm{o}}$} & \multicolumn{2}{|c|}{$70 \% \mathrm{~L}_{\mathrm{o}}$} \\
\hline & $\begin{array}{c}\text { TPT } \\
\mathrm{ms}\end{array}$ & $\begin{array}{c}1 / 2 \mathrm{RT} \\
\mathrm{ms}\end{array}$ & $\begin{array}{l}\text { TPT } \\
\text { ms }\end{array}$ & $\begin{array}{c}1 / 2 \mathrm{RT} \\
\mathrm{ms}\end{array}$ \\
\hline Before & $22.9 \pm 5.4$ & $41.7 \pm 6.8$ & $17.4 \pm 5.9$ & $15.0 \pm 5.5$ \\
\hline After $20 \mathrm{mg} \cdot l^{-1}$ & $21.8 \pm 5.8$ & $39.3 \pm 11.4$ & $20.0 \pm 5.9$ & $19.9 \pm 7.5$ \\
\hline Before & $23.2 \pm 5.2$ & $43.8 \pm 6.6$ & $16.9 \pm 5.7$ & $20.6 \pm 2.8$ \\
\hline After $100 \mathrm{mg} \cdot l^{-1}$ & $20.4 \pm 4.5$ & $48.3 \pm 6.5$ & $18.4 \pm 4.8$ & $29.8 \pm 7.9 *$ \\
\hline Before & $23.6 \pm 4.1$ & $40.4 \pm 8.0$ & $16.8 \pm 1.4$ & $19.6 \pm 9.1$ \\
\hline After $200 \mathrm{mg} \cdot l^{-1}$ & $21.9 \pm 5.7$ & $46.2 \pm 10.7 *$ & $17.8 \pm 1.8$ & $27.4 \pm 5.5^{*}$ \\
\hline Before & $17.8 \pm 3.9$ & $41.3 \pm 11.3$ & $16.2 \pm 1.8$ & $19.7 \pm 7.1$ \\
\hline After $400 \mathrm{mg} \cdot l^{-1}$ & $22.0 \pm 4.9 *$ & $43.2 \pm 8.7$ & $17.8 \pm 1.9^{*}$ & $25.3 \pm 6.9 *$ \\
\hline
\end{tabular}

Data are presented as mean \pm SD. $*: p<0.05$ compared to values obtained before theophylline. For abbreviations see legend to table 1 . 

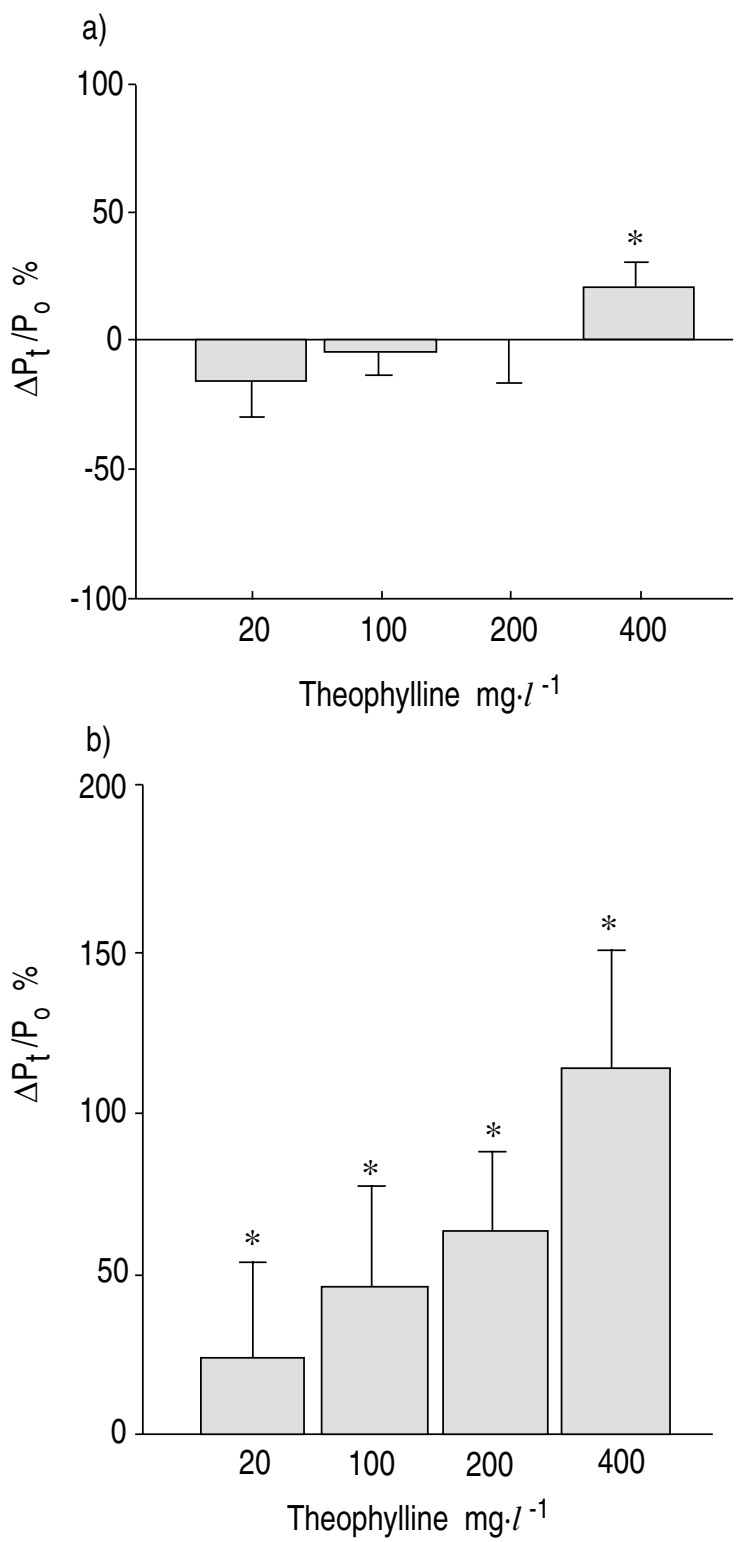

Fig. 2. - Effects of different theophylline concentrations on the twitch-tetanus ratio $\left(\mathrm{P}_{\mathrm{t}} / \mathrm{P}_{\mathrm{o}}\right)$ : a) at $100 \% \mathrm{~L}_{\mathrm{o}}$; and $\left.\mathrm{b}\right)$ at $70 \% \mathrm{~L}_{0}$. Data are presented as mean $\pm \mathrm{SD}$, expressed as a percentage of values obtained before theophylline. $*: p<0.05$. For abbreviations see legend to figure 1 .

Maximal tetanic force and twitch-tetanus ratio. Compared with data obtained before theophylline, $\mathrm{P}_{\mathrm{o}}$ significantly decreased after 20 or $100 \mathrm{mg} \cdot l^{-1}$ theophylline (fig. 1b). Other concentrations did not affect $\mathrm{P}_{0} \cdot \mathrm{P}_{t} / \mathrm{P}_{\mathrm{o}}$ increased with $400 \mathrm{mg} \cdot l^{-1}$ theophylline and decreased with the other concentrations. The changes in $\mathrm{P}_{\mathrm{t}} / \mathrm{P}_{\mathrm{o}}$ only reached statistical significance at 20 and $400 \mathrm{mg} \cdot l^{-1}(\mathrm{p}<0.05)$ (figs. $1 \mathrm{c}$ and 2a).

Effects of theophylline on contractile properties at $70 \% L_{o}$

Twitch characteristics. Compared with values obtained before theophylline, $\mathrm{P}_{\mathrm{t}}$ increased with increasing theophylline concentrations (fig. 1a). This increase, thus, exhibited a clear dose-response behaviour (e.g. $23 \pm 23$ and $74 \pm 34 \%$ at 100 and $400 \mathrm{mg} \cdot \mathrm{l}^{-1}$, respectively), and reached statistical significance at all concentrations except $20 \mathrm{mg} \cdot l^{-1}$. TPT significantly increased with $400 \mathrm{mg} \cdot l^{-1}$, and $1 / 2 \mathrm{RT}$ increased at all concentrations of theophylline, reaching statistical significance at 100, 200 and 400 $\mathrm{mg} \cdot l^{-1}$ (table 2). The prolonged 1/2RT was, however, not dose-related.

Maximal tetanic force and twitch-tetanus ratio. $\mathrm{P}_{\mathrm{o}}$ decreased at all theophylline concentrations (fig. 1b). This decrease reached statistical significance at all concentrations except at $400 \mathrm{mg} \cdot \mathrm{l}^{-1}$. The increase in $\mathrm{P}_{\mathrm{t}} / \mathrm{P}_{\mathrm{o}}$ observed at each theophylline concentration was significant, and exhibited a clear dose-response behaviour (figs. $1 \mathrm{c}$ and $2 \mathrm{~b}$ ). This was predominantly caused by an increase in $\mathrm{P}_{\mathrm{t}}$.

\section{Discussion}

The present data show that the inotropic effects of different theophylline concentrations on $\mathrm{P}_{t}$ and $\mathrm{P}_{t} / \mathrm{P}_{\mathrm{o}}$ of rat diaphragm in vitro are vastly greater at $70 \% \mathrm{~L}_{\mathrm{o}}$ than at $\mathrm{L}_{\mathrm{o}}$. The increase in $\mathrm{P}_{\mathrm{t}}$ and $\mathrm{P}_{\mathrm{t}} / \mathrm{P}_{\mathrm{o}}$ observed at $70 \% \mathrm{~L}_{\mathrm{o}}$ exhibits a clear dose-response behaviour. Moreover, the difference between the effect of theophylline at $70 \% \mathrm{~L}_{\mathrm{o}}$ and at $\mathrm{L}_{\mathrm{o}}$ also increases with increasing theophylline concentrations (fig. 1 and 2).

The effects of theophylline on contractile properties of the diaphragm have been studied extensively in vitro in small rodents [1-8], and more recently in dogs [9, 10]. Most of these studies, performed at $\mathrm{L}_{0}$, showed that the positive inotropic effects of theophylline occurred at considerably higher doses than those attainable in patients $[2-6,9,10]$. Our data obtained at $\mathrm{L}_{\mathrm{o}}$ with a theophylline concentration of $400 \mathrm{mg} \cdot l^{-1}$ are in keeping with these studies. At in vivo attainable serum levels, the effects of theophylline are highly controversial. In rodents, several in vitro studies demonstrated that theophylline improved diaphragm contractility [3, 4, 7, 8], and might exert a protective effect against fatigue [7], although the latter effect was not found in a recent study [8].

At low theophylline concentrations, our data show a tendency for $\mathrm{P}_{\mathrm{t}}$ and $\mathrm{P}_{\mathrm{t}} / \mathrm{P}_{\mathrm{o}}$ to decrease. This may be attributed to the appearance of a small degree of fatigue in the bundles during the experiment, as further reflected by the slight decrease in $\mathrm{P}_{\mathrm{o}}$ over time, or to a pharmacological effect of theophylline on $\mathrm{P}_{\mathrm{o}}$. However, as this decrease was not dose-dependent and was relatively constant, it was probably the result of fatigue. These findings are in line with previous reports that $\mathrm{P}_{\mathrm{t}} / \mathrm{P}_{\mathrm{o}}$ decreased during chronic stimulation of cat skeletal muscle [17]. In the present study, the prolonged 1/2RT observed after theophylline may reflect a pharmacological effect of theophylline, as previously demonstrated in the fatiguing diaphragm, where theophylline was shown to accentuate the slowing of relaxation caused by fatigue [18]. The physiological significance of this phenomenon is unknown.

Our results obtained at $\mathrm{L}_{\mathrm{o}}$ with low theophylline concentrations seem to be in apparent contradiction with previous studies in rats $[7,8]$. However, such discrepancy 
is likely to result from differences in methodology. KOLBECK and SPEIR [7] used a perfused, contracting intact rat diaphragm preparation, in which theophylline was added to the perfusion fluid. In this preparation, the diaphragm was supposedly placed at $\mathrm{L}_{\mathrm{o}}$, as evaluated by a length-tension study, although no actual length measurements were provided. As a consequence, foreshortening might have enhanced the inotropic effects of theophylline. In the study of KUEI and SIECK [8], theophylline was given by intravenous injection of aminophylline, and its effect was studied in vitro on innervated muscle strips. This study, however, was performed at $26^{\circ} \mathrm{C}$ rather than at $37^{\circ} \mathrm{C}$. The extrapolation of these findings to $37^{\circ} \mathrm{C}$ may be problematical.

Also, in dog and human studies, contradictory results have been obtained. Several studies have demonstrated that theophylline increased diaphragm force production [9, 11-13], and decreased fatigability [11], whilst others showed no effects on diaphragmatic contractility or fatigue $[10,19,20]$. These contradictory observations may be explained by interspecies differences in muscle fibre composition, and by a different sensitivity to the drug, as demonstrated previously for caffeine $[1,21]$, isoprenaline, and salbutamol [22].

The effects of theophylline on contractile properties of foreshortened diaphragm have, to the best of our knowledge, never been examined before. Compared with our data obtained at $\mathrm{L}_{\mathrm{o}}$, theophylline-induced effects on foreshortened diaphragm are vastly greater, and increase significantly with increasing theophylline concentration. Moreover, the decrease in $\mathrm{P}_{\mathrm{o}}$ observed during the experiment was more pronounced at $70 \% \mathrm{~L}_{\mathrm{o}}$ than at $\mathrm{L}_{\mathrm{o}}$, which is in line with previous observations on accelerated fatigue in foreshortened muscles [23].

The alterations of muscle mechanics with changes in acute shortening are well-known in skeletal muscles. Not only the sliding filament overlap [24], but also other factors play a role. Thus, in electrically stimulated muscle fibres, extreme shortening (less than $80 \% \mathrm{~L}_{\mathrm{o}}$ ) inhibits activation of central myofibrils [25], and decreases shortening velocity in the central sarcomeres [26]. Indeed, because of shortening, muscle fibres were swollen, thereby compressing the T-tubular system, and impeding exit electrolyte flow [27]. As a consequence, a failure of Ttubular conduction [25] and/or of calcium release from the sarcoplasmic reticulum may occur, leading to a decreased intracellular calcium concentration [26, 28]. Muscle shortening appears, therefore, to be associated with calcium deactivation.

The mechanisms by which theophylline induces inotropic effects at optimal length remain ill-defined. Several studies performed at $\mathrm{L}_{\mathrm{o}}$ have suggested that theophylline induced a hyperpolarization of the cell membrane [5, 29], or interacted with intracellular [30-32], or transmembrane $[32,33]$ calcium transfer, but not with cyclic adenosine monophosphate (cAMP) [32].

As theophylline's effects at shorter lengths have not been studied, one can only speculate on the mechanisms involved, envisioning a similar mechanism as proposed for caffeine. Indeed, like theophylline in the present study, caffeine potentiates twitch and tetanic tensions in a way inversely related to the cell length, these effects being associated with an increase in intracellular calcium concentration [26]. In addition, caffeine induces a synchronous contraction of the myofibrils at lengths below $\mathrm{L}_{\mathrm{o}}[25,26]$. Thus, we speculate that the greater effects of theophylline on $\mathrm{P}_{t}$ and $\mathrm{P}_{t} / \mathrm{P}_{\mathrm{o}}$ of foreshortened diaphragm bundles might result from increased calcium release and more homogeneous activation of the foreshortened muscle fibres, as demonstrated for caffeine [25, 26]. We hypothesized that the inotropic effect of theophylline at shorter diaphragm length could either result from a direct action of theophylline on sarcoplasmic reticulum channels, or from an action on T-tubular systems. Clearly, further studies are required to unravel these mechanisms.

However, it is worthwhile to consider that the present results pertain to an in vitro model and results may be different in vivo, where blood flow, among other factors, is maintained. Indeed, theophylline is a well-known vasodilating agent [34]. Thus, it is possible that by inducing systemic vasodilation, theophylline may also increase diaphragmatic blood flow, and thereby improve diaphragmatic force. However, several studies have demonstrated that diaphragmatic blood flow failed to increase after aminophylline [35-37], even when animals were breathing against an inspiratory resistive load [36, 37], thus, showing that aminophylline has no direct effect on diaphragmatic arterioles. Moreover, we recently compared in vivo the effects of aminophylline on canine diaphragm stimulated at functional residual capacity (FRC) and near total lung capacity (TLC) (producing a diaphragm shortening similar to that in the present in vitro study), and we observed results similar to those obtained in vitro [38].

The present results may be significant for the treatment of COPD patients. Although severe hyperinflation decreases airways resistance in these patients, it profoundly alters respiratory muscle function, presumably by shortening inspiratory muscles. As a consequence, the tension generated by these shortened muscles decreases as a result of both geometric changes and intrinsic length-tension characteristics. Moreover, adaptive changes to shortening, as occur during chronic hyperinflation in the diaphragm [15], are unlikely to occur with acute hyperinflation. Therefore, by increasing the force generated by shortened diaphragm, theophylline might contribute to improving respiratory muscle function in patients with acute hyperinflation.

Nevertheless, such increase in force production may involve a concomitant increase in oxygen consumption and substrate utilization by the muscle, which may enhance fatigability. This remains to be studied. In any event, the variability in theophylline-induced inotropic effects on diaphragm contractility is well known [7-11, 13, 20]. Our findings suggest this variability could be related to different degrees of hyperinflation in the patients studied, or to whether hyperinflation is acute or chronic.

In conclusion, the present study demonstrates greater inotropic effects of theophylline on $\mathrm{P}_{t}$ and $\mathrm{P}_{\mathrm{t}} / \mathrm{P}_{\mathrm{o}}$ of foreshortened rat diaphragm bundles. These effects are also observed at in vivo attainable serum levels and are 
dose-related. Whether or not these effects are clinically significant has to be determined. Studies on the effects of theophylline on respiratory variables in patients with acute hyperinflation are warranted.

\section{References}

1. Wittmann TA, Kelsen SG. The effect of caffeine on diaphragmatic muscle force in normal hamsters. Am Rev Respir Dis 1982; 126: 499-504.

2. Jones DA, Howell S, Roussos C, Edwards RHT. Lowfrequency fatigue in isolated skeletal muscles and the effects of methylxanthines. Clin Sci Lond 1982; 63: 161-167.

3. Supinski GS, Deal ED, Kelsen SG. Comparative effects of theophylline and adenosine on respiratory skeletal and smooth muscle. Am Rev Respir Dis 1986; 133: 809-813.

4. Viires N, Aubier M, Murciano D, Marty C, Pariente R. Effects of theophylline on isolated diaphragmatic fibers: a model for pharmacologic studies on diaphragmatic contractility. Am Rev Respir Dis 1986; 133: 1060-1064.

5. Esau SA. Effect of theophylline on membrane potential and contractile force in hamster diaphragm in vitro. $J$ Clin Invest 1986; 77: 638-640.

6. Reid MB, Miller MJ. Theophylline does not increase maximal tetanic force or diaphragm endurance in vitro. J Appl Physiol 1989; 67: 1655-1661.

7. Kolbeck RC, Speir WA. Diltiazem, verapamil, and nifedipine inhibit theophylline-enhanced diaphragmatic contractility. Am Rev Respir Dis 1989; 139: 139-145.

8. Kuei JH, Sieck GC. Chronic aminophylline administration: effect of diaphragm contractility and fatigue resistance in vitro. Am Rev Respir Dis 1991; 144: 121-125.

9. Derom E, Janssens S, De Bock V, Decramer M. Theophylline minimally alters contractile properties of canine diaphragm in vitro. J Appl Physiol 1990; 69: 1390-1396.

10. Janssens S, Derom E, Reid MB, Tjandramaga TB, Decramer M. Effects of theophylline on canine diaphragmatic contractility and fatigue. Am Rev Respir Dis 1991; 144: $1250-1255$.

11. Aubier M, De Troyer A, Sampson M, Macklem PT, Roussos C. Aminophylline improves diaphragmatic contractility. N Engl J Med 1981; 305: 249-252.

12. Supinski GS, Deal EC, Kelsen SG. The effects of caffeine and theophylline on diaphragm contractility. Am Rev Respir Dis 1984; 130: 429-433.

13. Murciano D, Aubier M, Lecocguic Y, Pariente R. Effects of theophylline on diaphragmatic strength and fatigue in patients with chronic obstructive pulmonary disease. $N$ Engl J Med 1984; 311: 349-353.

14. Decramer M. Effects of hyperinflation on the respiratory muscles. Eur Respir J 1989; 2: 299-302.

15. Oliven A, Supinski GS, Kelsen SG. Functional adaptation of diaphragm to chronic hyperinflation in emphysematous hamsters. J Appl Physiol 1986; 60: 225-231.

16. Decramer M, Jiang TX, Demedts M. Effects of acute hyperinflation on chest wall mechanics in dogs. $J$ Appl Physiol 1987; 63: 1493-1498.

17. Eerbeek O, Kernell D, Verhey BA. Effects of fast and slow patterns of tonic long-term stimulation on contractile properties of fast muscle in the cat. $J$ Physiol (Lond) 1984; 352: 73-90.

18. Esau SA. Slowing of relaxation in the fatiguing hamster diaphragm is enhanced by theophylline. J Appl Physiol 1988; 65: 1307-1313.
19. Moxham J, Miller J, Wiles CM, Morris A, Green M. Effect of aminophylline on the human diaphragm. Thorax 1985; 40: 288-292.

20. Kongragunta VR, Druz WS, Sharp JT. Dyspnea and diaphragmatic fatigue in patients with chronic obstructive pulmonary disease. Am Rev Respir Dis 1988; 137: 662-667.

21. Brust M. Fatigue and caffeine effects in fast-twitch and slow-twitch muscles of the mouse. Pfluegers Arch 1976; 367: 189-200.

22. Al-Jeboory AA, Marshall RJ. Correlation between the effects of salbutamol on contractions and cyclic AMP content of isolated fast- and slow-contracting muscles of the guinea-pig. Naunyn-Schmideberg's Arch Pharmacol 1978; 305: 201-206.

23. Farkas GA, Roussos C. Acute diaphragmatic shortening: in vitro mechanics and fatigue. Am Rev Respir Dis 1984; 130: 434-438.

24. Gordon AM, Huxley AF, Julien FJ. The variation in isometric tension with sarcomere length in vertebrate muscle fibers. J Physiol (Lond) 1966; 184: 170-192.

25. Taylor SR, Rüdel R. Striated muscle fibers: inactivation of contraction induced by shortening. Science 1970; 167: 882-884.

26. Lopez JR, Wanek LA, Taylor SR. Skeletal muscle: length dependent effects of potentiating agents. Science 1981; 214: 79-82.

27. Gonzalez-Serratos H, Somlyo AV, McClellan G, Shuman $\mathrm{H}$, Borrero LM, Somlyo AP. Composition of vacuoles and sarcoplasmic reticulum in fatigued muscle: electron probe analysis. Proc Natl Acad Sci USA 1978; 75: 1329_ 1333.

28. Ridgway EB, Gordon AM. Muscle activation: effects of small length changes on calcium release in single fibers. Science 1975; 189: 881-884.

29. Delbono O, Kotsias BA. Hyperpolarizing effect of aminophylline, theophylline and cAMP on rat diaphragm fibers. J Appl Physiol 1988; 64: 1893-1899.

30. Aubier M, Roussos C. Effect of theophylline on respiratory muscle function. Chest 1985; 88: 91S-97S.

31. Aubier M. Effect of theophylline on diaphragmatic and other skeletal muscle function. J Allergy Clin Immunol 1986; 78: 787-792.

32. Kolbeck RC, Speir WA. Theophylline, fatigue, and diaphragm contractility: cellular levels of $45 \mathrm{Ca}$ and cAMP. J Appl Physiol 1991; 70: 1933-1937.

33. Aubier M, Murciano D, Viires N, Lecocguic Y, Pariente R. Diaphragmatic contractility enhanced by aminophylline: role of extracellular calcium. J Appl Physiol: Respirat Environ Exercise Physiol 1983; 54: 460-464.

34. Rall TW. Drugs used in the treatment of asthma. The methylxanthines, cromolyn sodium and other agents. In: Goodman LS, Gilman A, eds. The Pharmacological Basis of Therapeutics. New York, MacMillan Co., 1990; pp. 618-630.

35. Mayock DE, Twiggs GA, Standaert TA, Watchko JF, Woodrum DE. The effect of aminophylline on diaphragm blood flow in the piglet. Pediatr Res 1989; 26: 196-199.

36. Mayock DE, Standaert TA, Woodrum DE. Effect of methylxanthines on diaphragmatic fatigue in the piglet. Pediatr Res 1992; 32: 580-584.

37. Derom E, Janssens S, Decramer M. Theophylline and respiratory muscle blood flow. Eur Respir J 1990; 3: 343S.

38. Gayan-Ramirez G, Palecek F, Chen Y, Janssens S, Decramer M. Inotropic effects of theophylline on foreshortened diaphragm. Am Rev Respir Dis 1992; 145: A669. 